\title{
KEBERADAAN HARTA PERKAWINAN \\ DALAM PROBLEMATIKA PERKAWINAN
}

\author{
Oleh : \\ Isetyowati Andayani
}

\begin{abstract}
Keeping house a lot of happened the problematika faced by husband and wife, what as a result cannot maintain the everlasting domesticity. Break the marriage nya can be happened because death, divorce and justice decision. While breaking marriage nya of because divorce, sure a lot of generating problems to "Their Marriage Estae".
\end{abstract}

Keyword : marriage Problems, It Broken Is Marriage, Marriage Estae

\section{PENDAHULUAN}

Akhir-akhir ini, makin maraknya perebutan harta perkawinan dalam kehidupan berumah tangga. Walaupun kita ketahui, bahwa tujuan perkawinan sudah diamanatkan dalam UndangUndang Perkawinan Nomor 1 Tahun 1974 (Vide pasal 1). Tujuan perkawinan pada dasarnya membentuk keluarga (rumah tangga) yang bahagia dan kekal berdasarkan Ketuhanan Yang Maha Esa yang didalam agama Islam dikenal kehidupan yang sakinah, mawadah dan warahmah.

Yang dimaksud dengan keluarga disini ialah satu kesatuan yang terdiri dari ayah (suami), Ibu (isteri) dan anak (anakanak apabila ada keturunan), yang merupakan sendi dasar dari susunan masyarakat (Indonesia).

Dalam mewujudkan kebahagiaan keluarga dibutuhkan suatu kesejahteraan dan ketenteraman keluarga. Hal ini bisa dilakukan saling menghargai dan menghormati masing-masing kehidupan suami, isteri dan anak-anaknya, yang nantinya diharapkan terwujudnya kekekalan dalam perkawinan (rumah tangga), yaitu bahwa seseorang hanya sekali melakukan perkawinan, tidak akan bercerai untuk selama-lamanya, dan hanya putus perkawinannya karena suatu kematian.

Namun dalam kenyataan perjalanan berumah tangga banyak terjadi problematika yang dihadapi oleh suami- 
isteri, yang akibatnya tidak dapat mempertahankan kehidupan rumah tangga yang kekal. Putusnya perkawinan dapat terjadi karena kematian, perceraian dan putusan pengadilan (Vide pasal 38 Undang-Undang Nomor 1 Tahun 1974). Kalau putusnya perkawinan karena kematian tidak banyak permasalahan yang timbul.

Namun arti tidak banyak disini, berarti juga masih ada permasalahan. Ada suatu kejadian bahwa suami-isteri sudah berpuluh-puluh tahun membina rumah tangga, namun tidak dikaruniai seorang anak pun.

Kemudian suaminya meninggal, dan ternyata timbul suatu persoalan bahwa keluarga si suami minta bagian harta perkawinan milik suami-isteri tersebut, hal inilah yang menimbulkan suatu permasalahan terhadap "Harta Perkawinan Mereka".

Sedangkan putusnya perkawinan karena perceraian, pasti banyak menimbulkan permasalahan. Seperti contoh suatu peristiwa tragis yang menimpa suami-isteri yang berebut harta perkawinan dalam proses perceraian diantara mereka. Sang suami (Irfan TNI
$A L)$ telah membunuh isterinya (Eka Suharti) dan hakim A. Taufiq saat sidang Pengadilan Agama Sidoarjo mengenai pembagian harta gono-gini antara Irfan dan Eka (Tanggal 21 September 2005). Kolonel Irfan tidak puas atas hasil putusan hakim Pengadilan Agama Sidoarjo menyangkut pembagian harta gono-gini. Peristiwa itu terjadi di ruang sidang 2 Pengadilan Agama Sidoarjo. Saat itu hakim memutuskan : "Harta dibagi dua, namun rumah milik Eka tidak masuk harta gono-gini karena merupakan hibah dari orang tua Eka". Sehingga contoh dari peristiwa tersebut, bahwa kedudukan harta perkawinan merupakan hal yang penting dalam suatu kehidupan berumah tangga.

Selain itu, problem harta perkawinan juga akan terjadi apabila suamiisteri mempunyai harta yang berlimpah, yang kemudian si suami, berkeinginan menikah untuk kedua kali atau lebih, tanpa atau ijin si isteri pertama, hal ini pun akan menimbulkan persoalan dalam kedudukan harta perkawinan mereka pada perkawinan yang terdahulu.

Problematika tentang harta perkawinan tersebut di atas, akan terjadi halhal sebagai berikut: 
1. Tentang kedudukan harta perkawinan terhadap perkawinan yang putus karena kematian dan perkawinan mereka tidak mempunyai keturunan (anak). Sedangkan keluarga yang ditinggalkan menginginkan harta perkawinan suamiisteritersebut.

2. Tentang kedudukan harta perkawinan akibat putusnya perkawinan karena perceraian, terhadap harta bersama atau harta yang diperoleh karena hibah, warisan dan sebagainya selama perkawinan.

3. Tentang kedudukan harta perkawinan akibat adanya perkawinan yang kedua dan seterusnya, dengan ijin maupun tanpa ijin dari isteri perkawinan yang terdahulu (yang pertama).

Sehingga dari beberapa hal tersebut di atas bahwa keberadaan harta perkawinan bagi suatu keluarga, yang terjadi suatu problema dalam rumah tangganya adalah sangat penting. Dari hal tersebut di atas akan di telaah keberadaan harta perkawinan dalam peraturan yang ada, sehingga timbullah suatu masalah sebagai berikut :

1) Bagaimana kedudukan harta per- kawinan dalam perundangan yang masih pluralistis?

2) Bagaimana upaya untuk mewujudkan kepastian hukum untuk keberadaan harta perkawinan?

\section{HUKUM KEKAYAAN DALAM HUKUM KELUARGA}

Mempelajari Hukum Harta Perkawinan tidak terlepas dari hubungan hukum antara seorang pria dan seorang wanita dengan tujuan membentuk suatu rumah tangga (keluarga) yang bahagia dan kekal berdasarkan Ketuhanan Yang Maha Esa. R. Soebekti mengatakan, bahwa Hukum Keluarga meliputi juga hubungan hukum dalam lapangan hukum kekayaan antara suami-isteri ( $R$. Soebekti, 1983 : 16). Hubungan hukum yang akan tercipta dari hubungan kekeluargaan meliputi antara lain :

1. Terjadinya perkawinan, yang akan memunculkan hubungan antara suami-istri (hak dan kewajiban-nya).

2. Hubungan hukum harta perkawin-an antara suami-isteri.

3. Hubungan antara orang tua dan anak.

4. Hubungan antara wali dengan anak perwaliannya, dan sebagainya.

Perkawinan mempunyai akibat 
hukum tidak hanya terhadap diri pribadi mereka-mereka yang melangsungkan pernikahan, hak dan kewajiban yang mengikat pribadi suami-isteri dan biasanya hak dan kewajiban inilah yang pertama-tama terpikir kalau kita bicara tentang hak dan kewajiban suami-isteri tetapi lebih dari itu mempunyai akibat hukum pula terhadap harta suami-isteri tersebut. Hubungan hukum kekeluargaan dan hubungan hukum kekayaan terjalin sedemikian eratnya, sehingga keduanya memang dapat dibedakan tetapi tidak dapat dipisahkan.

Hubungan hukum kekeluargaan menentukan hubungan hukum kekayaan dan hukum harta perkawinan tidak lain merupakan hukum kekayaan keluarga (J.G. Klaasen, $1956: 3$ ).

Hukum kekayaan keluarga masuk lingkup hukum perdata, sedangkan hukum perdata hingga sekarang ini masih bersifat pluralistis sebab sampai sekarang adanya beberapa macam sistem hukum perdata seperti sistem hukum barat (KUH Perdata/BW), sistem hukum nasional, sistem hukum adat (hukum tidak tertulis) dari orang Indonesia asli dan hukum adat dari golongan Timur Asing (Tionghoa dan Arab). Walaupun kita sudah tidak mengenal penggolongan penduduk dengan adanya Instruksi Presiden Kabinet tanggal 27 Desember 1966 No. 31/UJ/IN/12/1966, yang isinya antara lain : Penghapusan Golongan Penduduk dan hanya ada WNI dan WNA (Siti Suharnani, et. al., 2004, h.27).

\section{ISTILAH DAN BATASAN HUKUM HARTA PERKAWINAN}

Hukum Harta Perkawinan adalah peraturan hukum yang mengatur akibat-akibat perkawinan terhadap harta kekayaan suami-isteri yang telah melangsungkan perkawinan (J. J. Satrio, 1991 : 27). Untuk istilah "Hukum Harta Perkawinan" ada pula yang menggunakan istilah "Hukum Harta Benda Perkawinan" yang merupakan terjemahan dari kata Huwelijks goderen recht, sedangkan Hukum Harta Perkawinan sendiri merupakan terjemah-an dari Huwelijksvermogens recht. (Oetari Darmabrata, 1980: 185).

Istilah Hukum Harta Benda Perkawinan digunakan juga oleh Oetari S. Sadiono, 1954 : 92 (J. J. Satrio, 1991 : 27). Mengingat bahwa perkawinan adalah lembaga hukum yang merupakan unsur pokok daripada hukum keluarga, 
maka dari istilah "Hukum Harta Perkawinan" sudah dapatlah kita simpulkan adanya hubungan yang erat antara Hukum Harta Perkawinan dengan Hukum Keluarga dan kata "Harta" dalam istilah Hukum Harta Perkawinan mempersangkutkan adanya hubungan dengan Hukum Kekayaan (Vermogens recht) (J. J. Satrio; 1991 : 28).

HUKUM HARTA PERKAWINAN DALAM UU NO.1 TAHUN 1974

Pengaturan harta benda dalam perkawinan. Ada jenis harta perkawinan, yaitu : Harta Bersama dan Harta Bawaan. Harta Bersama yaitu harta yang diperoleh selama perkawinan (pasal 35 sub 1) yang dalam hukum adat disebut harta gono gini. Mengenai harta bersama suami-isteri tersebut dapat bertindak atas persetujuan kedua belah pihak (pasal 36 sub 1), Harta bawaan yaitu harta yang dibawa ke dalam perkawinan (dalam hukum adat : harta asal dan harta benda yang diperoleh masing-masing sebagai hadiah atau warisan tetap dalam penguasaan masingmasing, sepanjang para pihak tidak menentukan lain (pasal 35 sub 2)). Mengenai harta bawaan masing-masing, suami dan isteri mempunyai hak sepenuhnya untuk melakukan perbuatan hukum mengenai harta bendanya (pasal 36 sub 2). Bila perkawinan putus karena perceraian, harta bersama diatur menurut hukumnya masing-masing.

Sedangkan menurut hukumnya masing-masing dalam penjelasan pasal 37 yang dimaksud dengan hukumnya masing-masing ialah hukum agama, hukum adat dan hukum-hukum lainnya. Berkaitan pula dengan harta bersama, apabila perkawinan putus, maka harta bersama tersebut diatur menurut hukumnya masing-masing.

Dari hal tersebut di atas menunjukkan bahwa pengaturan hukum perkawinan khususnya harta bersama masih bersifat pluralistis. Antara pasal 37 dengan penjelasan pasal 35 yaitu yang mengatur tentang harta bersama sangat berlebihan. Dalam penjelasan pasal 35 disebutkan perkawinan putus, sedangkan pasal 37 perkawinan putus karena perceraian. Padahal putusnya suatu perkawinan dapat dikarenakan : a. kematian; b. perceraian dan c. atas keputusan pengadilan. Hal inilah yang 
dapat menimbulkan suatu penafsiran, khususnya penjelasan pasal 35 yang hanya menyebutkan perkawinan putus. Tidak disebutkan putus karena apa, sehingga dimungkinkan adanya penafsiran putusnya karena kematian atau keputusan pengadilan (putusan pengadilan inipun tidak jelas). Hal itu bisa terjadi putus karena perceraian sudah diatur dalam pasal 37 beserta penjelasannya pula.

Membaca pasal tentang harta perkawinan, sangatlah kurang lengkap, sedangkan problematika dalam harta perkawinan cukup banyak. Sehingga terjadilah banyak penafsiran, dan mengambil peraturan yang mengatur tentang harta perkawinan di luar Undang-Undang Nomor 1 Tahun 1974. Undang-Undang nomor 1 Tahun 1974 merupakan hukum nasional di-bidang hukum perkawinan.

HUKUM HARTA PERKAWINAN YANG BERLAKU MENURUT UNDANGUNDANG NOMOR 1 TAHUN 1974

Berlakunya UU Nomor 1 Tahun 1974 bertujuan untuk suatu Unifikasi dibidang Hukum Perkawinan. Namun setelah kita pelajari, ternyata masih menunjukkan sifat yang pluralistis, hal ini diwujudkan dalam pasal 2 ayat (1) dan pasal 66 Undang-UndangNomor 1 Tahun 1974. Ketentuan pasal 66 UU nomor 1 Tahun 1974 perlu ditelaah berkaitan dengan tidak lengkapnya peraturan tentang harta perkawinan dalam UndangUndang Nomor 1 Tahun 1974. Pasal 66 : "Untuk Perkawinan, maka dengan berlakunya Undang-undang ini, ketentuan-ketentuan yang diatur dalam Kitab Undang-Undang Hukum Perdata (Burgerlijk Wetboek), HOCI S. 1933. No. 74, R.GH. S., 1898. No.158 (Perkw campuran) dan peraturan-peraturan lain yang mengatur tentang perkawinan "Sejauh telah diatur" (tanda kutip oleh penulis) dalam Undang-Undang ini, dinyatakan tidak berlaku.

Dari pernyataan pasal tersebut menunjukkan bahwa pencabutan peraturan diluar Undang-Undang Nomor 1 Tahun 1974 adalah "Tidak Tegas" karena ada kalimat yang menyatakan sejauh telah diatur. Hal ini berlaku sebaliknya, bagaimana kalau tidak diatur oleh Undang-Undang Nomor 1 Tahun 1974, sedang peraturan yang lain mengatur. Menurut penulis, maka dengan menerap-kan penafsiran a contrario, maka peraturan yang lain tersebut dapat 
dipakai sebagailandasan hukum.

Penafsiran a contrario (menurut peringkaran), ialah suatu cara penafsiran Undang-Undang yang didasarkan pada perlawanan pengertian antara soal yang dihadapi dan soal yang diatur dalam suatu pasal Undang-Undang (CST Kansil, 1989 :69).

Dengan berlakunya UndangUndang Nomor 1 Tahun 1974 maka dikeluarkanlah peraturan pelaksanaannya yaitu Peraturan Pemerintah Nomor 9 Tahun 1975 (1 Oktober 1975). Ternyata hanya memuat peraturan pelaksanaan dari sebagian Undang-Uundang Nomor 1 Tahun 1974 saja dan pasal 35, 36 dan 37 yang mengenai Hukum Harta Perkawinan "belum tercakup didalamnya". Hal ini menimbulkan keragu-raguan pada pengadilan-pengadilan dan menangani perkara yang menyangkut maslah harta perkawinan. Kalau mencermati pengaturan harta benda dalam perkawinan dalam pasal 35 ayat (1) jo pasal 36 ayat (1) mengenai harta bersama dalam perkawinan, disini kurang jelas mengenai kalimat "diperoleh selama perkawinan". Timbul suatu persoalan bagaimana apabila salah satu pihak atau masingmasing pihak memperoleh harta melalui hibah dari keluarganya, atau mendapat warisan pada saat "selama perkawinan". Apakah hal ini masuk harta bawaan atau harta bersama. Hal ini menimbulkan permasalahan.

Demikian juga terhadap pasal 35 ayat (2) jo pasal 36 ayat (2) tentang harta bawaan dalam perkawinan, yang juga timbul persoalan ketika harta bawaan tersebut dijual dan hasil penjualannya dibelikan suatu barang yang kemudian atas barang tersebut tercampur dalam harta bersama, apakah hukum menganggap barang tersebut sebagai harta bersama dalam perkawinan, karena ketidakjelasan pengaturan harta benda perkawinan akan menimbulkan penafsiran yang bermacam-macam sesuai kepentingan-kepentingan yang ada.

Bunyi pasal 35 dan 36 UndangUndang Nomor Tahun 1974 tentang harta bersama dan harta bawaan dalam prakteknya memang memberatkan bagi suami atau isteri untuk menikmati hak milik atas harta yang jelas-jelas 
merupakan hasil perolehannya sendiri. Kemudian yang memberatkan bagi suami-isteri terhadap harta bersama yang juga dimungkinkan hasil dari jerih payahnya sendiri (khususnya si isteri), yang dalam hal misalnya mengalihkan, harus ada persetujuan kedua belah pihak (suami-isteri). Apabila dikaitkan dengan pasal $570 \mathrm{KUH}$ Perdata tentang hak milik, hal ini akan bertentangan. Pasal $570 \mathrm{KUH}$ Perdata menyatakan bahwa hak milik adalah hak untuk menikmati kegunaan sesuatu kebendaan dengan leluasa, dan untuk berbuat bebas terhadap kebendaan itu dengan kedaulatan sepenuhnya, asal tidak bersalahan dengan undang-undang atau peraturan umum yang ditetapkan oleh suatu kekuasaan yang berhak menetapkannya, dan tidak mengganggu hak-hak orang lain.

\section{PERATURAN HARTA PERKAWINAN DILUR UU NO.1 TAHUN 1974}

Berdasarkan pasal 66 UndangUndang Nomor 1 Tahun 1974 (dalam penafsiran a contrario ) dan diperkuat dengan Surat Mahkamah Agung (MA), yaitu MA/Pemb/0807/1975 dengan judul "Petunjuk-petunjuk MA Mengenai Pelaksanaan Undang-Undang Nomor 1
Tahun 1976 dan Peraturan Pemerintah (PP) Nomor 9 Tahun 1975" dimana pada sub 4 dikatakan, bahwa tentang Harta Benda dalam Perkawinan ternyata tidak diatur dalam PP tersebut (PP. Nomor 9 Tahun 1975), karenanya belum dapat diperlakukan secara efektif dan dengan sendirinya untuk hal-hal itu masih diperlakukan ketentuan-ketentuan hukum dan perundang-undangan lama (J. Satrio, $1991: 9)$.

Walaupun surat Mahkamah Agung tersebut bukan merupakan ketentuan umum namun hanya ditujukan pada keadaan konkrit apabila ada permasalahan yang dihadapi oleh pengadilan, hal inipun secara tidak langsung surat MA tersebut mempunyai daya mengikat umum sehingga patut untuk diperhatikan.

\section{HUKUM HARTA PERKAWINAN DALAM KUH PERDATA}

Masih berlakunya KUH Perdata dalam keberadaan harta perkawinan, hal ini pernah ada keputusan MA tanggal 15 Februari 1977 No. 726K/Sip/1976, dalam mana dipertimbangkan, bahwa "sekalipun Undang-Undang Nomor1 Tahun 1974 telah berlaku, tetapi untuk pe- 
laksanaannya masih memerlukan peraturan pelaksanaan dan karena hingga kini peraturan pelaksanaan yang mengatur sebagai pengganti ketentuanketentuan yang dalam BW belum ada, maka bagi penggugat dan tergugat yang adalah WNI Keturunan Cina masih berlaku ketentuan-ketentuan mengenai perkawinan yang tercantum dalam $\mathrm{KUH}$ Perdata (J. Satrio, 1991 : 11).

Dari hal tersebut di atas di artikan masih diberlakukan ketentuanketentuan hukum dan perundangundangan lama. Namun untuk tunduk pada peraturan KUH Perdata mengenai harta benda perkawinan, maka berbeda dengan Undang-Undang Nomor 1 Tahun 1974, karena dalam KUH Perdata, apabila terjadi perkawinan maka hanya ada kebersama-an (kebulatan) harta benda perkawinan. Hal ini memang berbeda dengan Undang-Undang Nomor 1 Tahun 1974 yang mengenal jenis harta perkawinan ada 2 (dua) yaitu harta bersama dan harta bawaan.

Selanjutnya menuurut J. J. Satrio dengan perkataan lain sepanjang mengenai harta perkawinan paling tidak untuk mereka yang tunduk pada BW Undang-Undang Perkawinan belum berlaku, dan pada umumnya para notaris juga menafsirkan surat MA tersebut, seperti itu (J. Satrio, 1991 : 11) Juga Soebekti menafsirkan surat MA tersebut seperti itu, walaupun beliau berpendapat, bahwa surat tersebut paling tidak sepanjang mengenai Hukum Harta Perkawinan sebenarnya tidak perlu. Sedangkan Tahir Tungadi, berpendapat, bahwa surat tersebut hanya benar untuk mereka yang menikah sesudah berlakunya Undang-Undang Perkawinan (J. Satrio, 1991 : 11).

\section{HUKUM HARTA PERKAWINAN ME- NURUT HUKUM ADAT}

Dalam hukum adat dikenal adanya harta gono-gini, dan harta pusaka atau harta asal. Dalam kamus umum Bahasa Indonesia, gono-gini diartikan sebagai harta perolehan bersama selama bersuami-isteri. Diartikan pula bahwa gono-gini adalah harta benda perkawinan yang diperoleh oleh suami-isteri selama perkawinan dan menjadi hak milik suamiisteri. ( Dalam bahasa Inggris : gono-gini is property acquired jointly, especially during marriage, and which is divided equally in event of divorce). Sedangkan harta asal lebih dikenal dengan harta 
bawaan, yaitu harta yang dimiliki oleh masing-masing suami-isteri sebelum dilangsungkan suatu perkawinan.

Jadi, jenis harta benda perkawinan menurut hukum adat sama dengan Harta Benda Perkawinan yang diatur dalam Undang-Undang Nomor 1 Tahun 1974. Hal ini sesuai dengan pendapat pakar hukum perdata Soebekti : "Memang masalahnya menjadi lain, kalau peraturan pelaksanaan yang akan dipinjam adalah dari Hukum Adat, karena menurut Hukum Harta Perkawinan menurut UU Perkawinan mendasarkan pada Hukum Adat (R. Soebekti, 1983 : 2).

Hal ini bukan berarti yang dipakai adalah hukum adat, tetapi bahwa yang dipakai adalah Undang-Undang Nomor 1 Tahun 1974 yang mempunyai prinsip yang sama dengan hukum adat, karena "asasnya sama" (yaitu : ada harta gono-gini at harta bersama dan harta bawaan masing-masing tetap terpisah).

Kenyataan bahwa Pengadilan paling tidak sebagian tanpa penjelasan apa-apa masih menggunakan istilahistilah adat, memberikan petunjuk bahwa pengadilan masih berpendapat bahwa bagi mereka yang tunduk pada hukum adat sepanjang mengenai atau berkaitan dengan Hukum Harta Perkawinan masih berlaku Hukum Adat. Pendapat dan pikiran seperti tersebut di atas berlangsung bertahun-tahun, sampai MA memberikan suatu keputusan yang mengejutkan paling tidak untuk dunia perbankan dan para notaris (Rasyim Wiraatmaja, 1990 : 84), yaitu Keputusan No. 2690K/Pdt/1985 yang menetapkan, bahwa untuk penjualan Harta Bersama harus ada persetujuan dari suami/ isterinya. Dan persetujuan disini diartikan sebagai persetujuan secara tegas.

Sekalipun keputusan tersebut hanya memberikan hukum untuk kasus mana keputusan tersebut diberikan (bukan merupakan suatu ketentuan umum), namun mengingat bahwa MA adalah penjaga gawang yang terakhir dan peradilan tertinggi dalam sengketa hukum, keputusan tersebut dapat mempunyai pengaruh yang sangat luas, apalagi sehubungan dengan keputusan tersebut. Dengan adanya hukum adat dalam bidang Harta benda perkawinan yang berkaitan dengan Undang-Undang Nomor 1 Tahun 1974. menurut Purwoto, bahwa Undang-Undang Nomor 1 Tahun 1974 sebagai hukum nasional mengikuti system Hukum Adat (Purwoto $S$ 
Gandasubrata, 1990 : 96).

Apabila para pihak tunduk pada hukum adat dan antara hukum adat dan Undang-Undang Nomor 1 Tahun 1974 dalam lapangan Hukum Harta Benda Perkawinan, hal ini tidak menimbulkan masalah karena ada persamaan dalam asasnya (adanya harta bersama atau gono-gini, dan harta asal atau harta bawaan yang diwakili oleh masingmasing pihak). Jadi sebenarnya yang sering membingungkan adalah pasal tentang harta bersama (pasal 35 ayat (1) UU No.1 Tahun 1974 yaitu kalimat "yang diperoleh selama perkawinan". Permasalahannya yaitu apabila seorang suami atau isteri yang memperoleh hadiah atau warisan dari orang tua atau pihak ketiga pada saat sudah dalam ikatan perkawinan (selama perkawinan). Harta perkawinan tersebut masuk dalam harta bersama (pasal 35 ayat (1)) atau masuk harta bawaan (pasal 35 ayat (2)). Hal ini yang menimbulkan masalah karena menimbulkan penafsiran adanya pembenturan antara pasal 35 ayat (1) dan pasal 35 ayat (2) tentang perolehan hadiah atau warisan selama perkawinan. Menurut hemat saya, hadiah dan warisan tersebut masuk dalam harta bawaan walaupun perolehannya selama perkawinan.

\section{HUKUM HARTA PERKAWINAN MENURUT KOMPILASI HUKUM ISLAM (KHI)}

Dalam kompilasi Hukum Islam yang berlaku dalam lingkungan Pengadilan Agama, harta gono-gini disebut dengan istilah harta kekayaan dalam perkawinan atau syirkah adalah harta yang diperoleh baik sendiri-sendiri atau bersama suami-isteri selama dalam ikatan perkawinan berlangsung dan selanjutnya disebut harta bersama, tanpa mempersoalkan terdaftar atas nama siapapun (pasal 1 ayat (1)).

Dalam perspektif fiqih Islam, sebagian ulama menganggap harta gonogini sebagai harta syirkah. Memamng benar termasuk syirkah, tetapi menurut pemahaman kami, bukan syirkah akad (syirkah uqud), seperti syirkah abdan, syirkah inan dan syirkah mudharabah, melainkan syirkah kepemilikan (Syirkah Milk/Syirkah Amlak. Adapun definisi sirkah kepemilikan ini adalah kepemilikan bersama atas suatu barang di antara dua orang atau lebih yang terjadi karena adanya salah satu sebab kepemilikan 
(seperti jual-beli, hibah, wasiat dan waris atau karena adanya percampuran harta benda yang sulit untuk dipilah-pilah dan dibedakan. Syirkah kepemilikan ini misalnya ada satu pihak yang menghibahkan suatu harta kepada 2 (dua) orang, lalu keduanya menerimanya maka kepemilikan harta itu dalam Fiqih Islam disebut syirkah kepemilikan (Syirkah milik/syirkah amlak).

Harta kekayaan dalam perkawinan menurut Kompilasi Hukum Islam (KHI) mengenai harta kekayaan dalam perkawinan, bahwa mengenai harta bersama dan harta bawaan (milik masingmasing suami-isteri), tidak didefinisikan secara tegas, namun tersirat dalam pasal 85 Kompilasi Hukum Islam yang mengakui adanya harta bersama dan harta milik masing-masing suami-isteri.

Dalam Kompilasi Hukum Islam menegaskan pula bahwa pada "dasarnya" tidak ada percampuran antara harta suami dan harta isteri karena perkawinan (pasal 86 ayat (1)). Selanjutnya harta isteri tetap menjadi hak isteri dan di kuasai penuh olehnya, demikian juga harta suami tetap menjadi hak suami dan di kuasai penuh olehnya (pasal 86 ayat (2)).
Harta bawaan dari masingmasing suami dan isteri dan harta yang diperoleh masing-masing sebagai hadiah atau warisan adalah di bawah pengawasan masing-masing, sepanjang para pihak tidak menentukan lain dalam "perjanjian perkawinan”. Selanjutnya, bahwa suami dan isteri mempunyai hak sepenuhnya untuk melakukan perbuatan hukum atas harta masing-masing berupa hibah, hadiah, sodaqoh atau lainnya (Pasal 87 ayat $(1,2)$.

Dari pasal tersebut di atas mengenai harta kekayaan dalam perkawinan. Bahwa Kompilasi Hukum Islam juga mengenal dua jenis harta perkawinan, yaitu harta bersama dan harta bawaan dari masing-masing suami dan isteri. Namun dalam Kompilasi Hukum Islam tidak disebutkan sejak kapan disebut harta bersama dan harta bawaan. Hal ini berbeda dengan definisi harta perkawinan (harta bersama dan harta bawaan yang diatur dalam Pasal 35 ayat $(1,2)$ UU No.1 Tahun 1997. Tetapi, kalau kita telaah dalan Undang-Undang Nomor 1 Tahun 1974 khususnya terhadap bunyi pasal 35 ayat (1), yaitu kalimat "diperoleh selama perkawinan" (harta bersama), hal ini menimbulkan multi tafsir, 
contohnya seperti tentang harta warisan, hibah yang diperoleh "selama perkawinan", menjadi harta bersama, atau harta bawaan. Walaupun dalam Pasal 35 ayat (2) Undang-Undang Nomor 1 Tahun 1974 sebagai harta bawaan.

Kalau dibandingkan dalam $\mathrm{KHI}$ lebih jelas tentang harta bersama dan harta bawaan. Hal ini tersurat dalam Pasal 87 ayat (1) Kompilasi Hukum Islam dan harta yang diperoleh masing-masing sebagai "hadiah atau warisan" adalah dibawah penguasaan masing-masing, Disini tidak menyebutkan waktunya, misalnya "selama perkawinan", sehingga tidak menimbulkan multi tafsir. Yang terpenting bahwa harta dari hadiah atau warisan adalah hak masing-masing suami atau isteri, tidak melihat pemberian tersebut sebelum, atau selama perkawinan.

\section{HARTA PERKAWINAN DALAM PERSPEKTIF ISLAM}

Dalam Islam harta yang diperoleh isteri dari hasil kerjanya sendiri tidak termasuk harta gono-gini (harta bersama), karena harta tersebut adalah hak milik isteri. Hal itu berdasarkan firman Allah SWT (artinya) : "Bagi para laki-laki ada bagian dari apa yang mereka usahakan, dan bagi para wanita pun ada bagian dari apa yang mereka usahakan (QS. An-Nisaa : 32). Sehingga apabila isteri bekerja dan memperoleh harta, maka isteri punya hak penuh atas hartanya itu. Jika isteri mau menggunakan harta itu untuk keperluan keluarga, maka itu dianggap sebagai sedekah yang punya dua pahala, yakni pahala sedekah dan pahala berbuat baik kepada keluarga.

Hak milik isteri adalah harta yang sudah dimiliki isteri sebelum pernikahan dan harta milik isteri yang berasal dari warisan, hadiah, hibah, pihak ketiga, juga mahar dari suami. Juga harta yang diperoleh dari hasil kerja isteri. Semua itu harta milik (harta bawaan isteri). Kecuali, jika isteri menggunakan hartanya itu untuk keperluan keluarga dan dijadikan hak milik bersama (syirkah amlak), misalnya uang yang semula milik isteri diberikan kepada suami, lalu suami menggabungkan uang isteri tersebut dengan uang suami yang selanjutnya menjadi harta bersama.

Bagi mereka yang beragama Islam, apabila terjadi perselisihan antara 
suami-isteri tentang harta bersama, maka penyelesaian perselisihan itu diajukan kepada Pengadilan Agama. Sebaliknya bagi mereka yang bukan beragama Islam diajukan ke Pengadilan Negeri. Apabila suami-isteri putus perkawinannya karena kematian, maka hak pasangan yang hidup lebih lama mendapat separoh harta bersama.

Apabila putusnya perkawinan karena perceraian masing-masing pihak (suami, isteri) mendapat seperdua dari harta bersama. Tetapi aturan tersebut dapat disimpangi melalui perjanjian kawin. Sehingga hal ini dapat disimpulkan bahwa menurut ketentuan dalam Kompilasi Hukum Islam tersebut bahwa pembagian harta perkawinan tidak wajib, melainkan "mubah" (boleh), sehingga sengketa harta bersama dapat dilakukan di luar Pengadilan Agama, berdasarkan musyawarah dengan menempuh jalan perdamaian (Ash-Shuluh).

Dalam Kompilasi Hukum Islam, walaupun tidak ada definisi tentang harta bersama namun bisa diartikan dari pengertian harta bawaan. Jadi harta bersama adalah harta diluar harta bawaan hadiah masing-masing suamiisteri, dan tidak termasuk harta atau warisan sebelum perkawinan atau selama perkawinan. Apabila hakim memutuskan bahwa harta warisan yang diperoleh selama perkawinan tetap dikuasai oleh masing-masing penerima atau masuk harta bawaan adalah sudah tepat. Hal ini bisa mempertegas Pasal 35 ayat (2) Undang-Undang Nomor 1 Tahun 1974 (tentang harta bawaan).

Apabila suami mempunyai isteri lebih dari seorang, maka harta bersama dari perkawinan mereka, masing-masing terpisah dan berdiri sendiri (Pasal 94 ayat 1). Dari pernyataan Pasal 94 ayat (1) di atas maka dihitung pada saat berlangsungnya akad perkawinan yang kedua, ketiga atau yang keempat. Untuk mengatur lebih jelas dan tidak menimbulkan multi tafsir terhadap harta perkawinan dapat melalui perjanjian kawin.

\section{PERJANJIAN KAWIN}

\section{Arti dan Tujuan Perjanjian Kawin Menurut KUH Perdata}

Perjanjian kawin (Huwelijks atau Huwelijkse voor warden) adalah perjanjian yang dibuat oleh dua orang calon suami-isteri sebelum dilangsungkannya perkawinan mereka, untuk mengatur akibat-akibat perkawinan 
yang menyangkut harta kekayaan. Perjanjian kawin ini lebih bersifat hukum kekeluargaan (Familie rechtelijk) sehingga tidak semua ketentuan hukum perjanjian yang terdapat dalam buku III BW, berlaku misalnya suatu aksi (gugat) berdasarkan suatu kekhilafan (Dwaling I error) tidak dapat dilakukan (R. Soetojo P., Marthalena Pohan, 1990 : 74).

Menurut Pitlo, di Netherland tidak banyak orang yang kawin dengan perjanjian kawin. Perjanjian kawin itu dibuat dengan tujuan : (R. Soetodjo P, Marthalena Pohan, $1990: 74$ )

1. "Membatasi atau meniadakan sama sekali "kebersamaan harta kekayaan menurut Undang-Undang".

2. Pemberian-pemberian hadiah (schenking) dari suami kepada isteri atau sebaliknya, atau pemberian hadiah timbal-balik antara suami dan isteri (Pasal 168 KUH Perdata).

3. Membatasi kekuasaan suami "terhadap barang-barang kebersamaan yang ditentukan oleh Pasal 124 ayat (2) KUH Perdata, sehingga "tanpa bantuan" isterinya, sang suami tidak dapat melakukan perbuatanperbuatan yang bersifat memutus (beschikken). Hal yang sama berlaku juga terhadap benda-benda bergerak maupun tak ber-gerak yang dibawa istri (aanbrengst) atau terhadap benda-benda yang diperolehnya sepanjang perkawinan yang beratasnamakan istri (Pasal 140 ayat (3) KUH Perdata).

4. Sebagai testamen dari suami untuk isteri atau sebaliknya, atau testamen timbal-balik (Pasal 169 KUH Perdata).

5. Pemberian hadiah (schenking) oleh "pihak ketiga" kepada suami dan atau isteri (Pasal 176 KUH Perdata).

6. Sebagai testamen dari "pihak ketiga" kepada suami dan ataau isteri (Pasal 178 KUH Perdata).

Baik testament maupun schenking yang dimaksud oleh sub 4 hingga 6 mungkin saja terjadi, jika kebersamaan harta kekayaan dibatasi atau ditiadakan. Di lain pihak, dalam hal sub 5 dan sub 6 seperti yang telah disebutkan, perjanjian kawin tersebut tidak hanya mengikat suami dan isteri saja, akan tetapi juga mengikat pihak ketiga yang menjadi pihak (Partij) dalam perjanjian tersebut dan ikut serta menanda-tangani aktenya. 
Pada Umumnya Perjanjian Kawin dibuat: (R. Soetojo P, 1988)

1) Bilamana terdapat sejumlah harta yang lebih besar pada salah satu pihak daripada pihak yang lain.

2) Kedua belah pihak masing-masing membawa masukan (aan brengst) yang cukup besar.

3) Masing-masing mempunyai usaha sendiri-sendiri, sehingga andaikata salah satu jatuh "failiet", yang lain tidak tersangkut.

4) Atas hutang-hutang yang mereka buat sebelum kawin, masingmasing akan bertanggung gugat sendiri-sendiri.

Maksud pembuatan perjanjian kawin ini adalah untuk mengadakan penyimpangan terhadap ketentuanketentuan tentang harta kekayaan bersama seperti yang ditetapkan dalam Pasal 119 KUH Perdata. Para pihak adalah bebas untuk menentukan bentuk hukum yang dikehendakinya atas harta kekayaan yang menjadi obyeknya. Mereka dapat saja menentukan, bahwa didalam perkawinan mereka sama sekali tidak akan terdapat kebersamaan harta kekayaan (uits/uiting van gemeenchap van goederen) atau kebersamaan harta kekayaan yang terbatas (beperkte gemeenschap van goederen).

BENTUK DAN BERLAKUNYA PERJANJIAN KAWIN MENURUT KUH PERDATA

Perjanjian kawin menurut $\mathrm{KUH}$ Perdata harus dibuat dengan akte notaris (Pasal 147 KUH Perdata) dan dibuat pada saat sebelum perkawinan dilangsungkan. Apabila salah satu dari kedua syarat itu tidak dipenuhi, maka perjanjian kawin itu batal demi hukum (van rechts wege nietig). Sehingga hal ini mengakibatkan adanya anggapan ada kebersamaan harta kekayaan antara suami-isteri didalam perkawinan tersebut. Perjanjian kawin dibuat dengan akte notaris :

a. Diadakan untuk memperoleh "kepastian tentang tanggal pembuatan perjanjian kawin". Apabila orang diperbolehkan membuat perjanjian kawin dengan akte dibawah tangan, maka ada kemungkinan terjadi pemalsuan tanggal akte (disantedateer) dan pembuatan perjanjian setelah perkawinan dilangsungkan (pasal 
149 KUH Perdata).

b. Diadakan dengan maksud agar setelah perkawinan dilangsungkan dapat diketahui dengan pasti, mengenai perjanjian kawin berikut isi perjanjian kawin itu. Perjanjian kawin berlaku sepanjang perkawinan berlangsung dan tidak dapat diubah (Pasal 149 KUH Perdata).

Apabila perkawinan belum dilangsungkan, maka perjanjian itu masih dapat diubah. Menurut ketentuan Pasal 148 ayat (1) KUH Perdata perubahannya harus dilakukan dengan akte notaris. Perubahan tersebut dianggap sah jika disepakati oleh mereka yang dahulu menjadi pihak (partij). Selanjutnya Pasal 148 ayat (2) KUH Perdata menyebutkan "Tidak hanya mereka saja yang memberikan ijin kesepakatan, akan tetapi juga mereka yang memberikan hadiah (schenking) pada calon suami-isteri.

Perjanjian kawin dengan akte notaris. Hal ini dilakukan, kecuali untuk "keabsahan" perjanjian kawin, juga : (R. Soetojo Prawirohamidjojo, 1988: 59)

a) Untuk mencegah perbuatan yang tergesa-gesa, oleh karena akibat daripada perjanjian ini akan dipikul untuk seumur hidup.

b) Untuk adanya kepastian hukum.

c) Sebagai satu-satunya alat bukti yang sah.

d) Untuk mencegah kemungkinan adanya penyelundupan atas ketentuan pasal $149 \mathrm{KUH}$ Perdata (setelah dilangsungkannya perkawinan, maka dengan cara apapun juga, perjanjian kawin itu tidak dapat diubah).

\section{PERJANJIAN KAWIN MENURUT Undang-Undang Nomor 1 TAHUN 1974}

$$
\text { Perjanjian kawin didalam }
$$
Undang-Undang Nommor 1 Tahun 1974, hanya diatur oleh satu pasal yaitu Pasal 29 dan 4 ayat. Bahwa ayat-ayat dalam pasal 29 tidak mengatur bentuk-bentuk harta benda dalam perkawinan secara terperinci. Pasal tersebut hanya mengatur tentang saat perjanjian kawin itu dibuat, tentang keabsahannya, tentang saat berlakunya dan tentang dapat diubahnya perjanjian tersebut. Jadi tidak mengatur tentang isi dari perjanjian kawin seperti halnya pada KUH Perdata.

Dalam Pasal 29 ayat (1) : pada waktu atau sebelum perkawinan di- 
langsungkan, kedua pihak atas persetujuan bersama dapat mengadakan perjanjian tertulis yang disahkan oleh Pegawai Pencatat Perkawinan, setelah mana isinya berlaku juga terhadap pihak ketiga sepanjang pihak ketiga tersangkut. Dari bunyi pasal tersebut dapat ditarik kesimpulan, bahwa bentuk perjanjian perkawinan adalah tidak harus otentik. Yang artinya bebas, bisa akta otentik atau akta dibawah tangan, asalkan tertulis. Padahal dalam kenyataannya : pejabatpejabat catatan sipil dan beberapa notaris baik di Surabaya maupun di Jakarta, bahwa mereka yang membuat perjanjian kawin masih selalu minta bantuan notaris : (R. Soetojo Prawirohamidjojo, 1988 : 60).

1. Karena mereka merasa sebagai "man in the street".

2. Karena mereka menaruh kepercayaan yang cukup besar kepada para pejabat tersebut, sebab perjanjiannya dibuat oleh pejabat yang memang ahli di dalam bidangnya, sehingga mereka merasa aman.

Untuk pengesahannya, yang diberi wewenang oleh Undang-Undang ialah pegawai pencatat perkawinan, yaitu pegawai pencatat nikah, talak dan rujuk bagi mereka beragama Islam dan pegawai catatan sipil bagi mereka yang bukan Islam. Pengesahan akan diberikan apabila tidak melanggar norma agama, norma kesusilaan, norma hukum, norma kesopanan (Pasal 29 ayat (2) UndangUndang Nomor 1 Tahun 1974). Walaupun dalam Pasal 29 ayat (2) Undang-Undang Nomor 1 Tahun 1974 menyebutkan batasbatas namun yang tepat adalah "normanorma" karena kalau "norma" isinya ada perintah dan larangan, namun kalau batas tidak ada perintah dan larangan.

Perjanjian kawin tersebut mulai berlaku sejak perkawinan dilangsungkan, yang artinya tidak dapat ditentukan waktu yang lain (Pasal 29 ayat (3) UndangUndang Nomor 1 Tahun 1974), hal ini juga dimaksudkan agar ada kepastian hukum pada saat perkawinan dan selanjutnya terhadap harta perkawinan mereka. Sebaliknya perjanjian kawin menjadi gugur bila perkawinan itu tidak jadi dilangsungkan.

Selama perkawinan berlangsung perjanjian tersebut tidak dapat dirubah, kecuali bila dari kedua belah pihak ada persetujuan untuk merubah dan 
perubahan tidak merugikan pihak ketiga (Pasal 29 ayat (4) Undang-Undang Nomor 1 Tahun 1974). Ketentuan ini kiranya diambil alih dari N.B.W. sebagai kelanjutan Undang-Undang 1956. Dalam N.B.W Boek I artikel 119 ayat (1) dan (2) disebutkan bahwa untuk dapat mengubah perjanjian kawin harus mengajukan permohonan kepada pengadilan (Rechtbank) dan diumumkan melalui minimum dua surat kabar yang dahulu mengumumkan perjanjian kawin tersebut. Sedangkan Undang-Undang kita (Undang-Undang Nomor 1 Tahun 1974 ) mengenai hal ini diam (R. Soetojo Prawirjohamidjojo, 1988:61).

Dalam penjelasan Pasal 29 tidak termasuk talik-talak, jadi menurut Undang-Undang Nomor 1 Tahun 1974 yang boleh diperjanjikan hanya mengenai kedudukan "harta perkawinan" suami-isteri setelah melangsungkan perkawinan. Sehingga hal ini tidak termasuk janji-janji selain yang mengatur harta perkawinan. Hal ini sama dengan KUH Perdata (tentang harta perkawinan). Tetapi tidak halnya dalam Kompilasi Hukum Islam. Dan aturan dalam UndangUndang Nomor1 Tahun 1974 tentang perjanjian kawin sangat minim hanya satu pasal dan 4 ayat saja. Hal ini berbeda dengan KUH Perdata maupun Kompilasi Hukum Islam.

\section{PERJANJIAN KAWIN MENURUT KHI}

Dalam hukum Islam perjanjian kawin lebih dikenal dengan istilah perjanjian Pra Nikah. Dalam Kompilasi Hukum Islam juga menentukan waktu pembuatan perjanjian kawin yaitu : Pada waktu atau sebelum perkawinan dilangsungkan kedua calon mempelai dapat membuat perjanjian tertulis yang di sahkan pegawai pencatat nikah mengenai kedudukan harta dalam perkawinan (Pasal 47 ayat (1) Kompilasi Hukum Islaml). Berarti disini bentuknya tidak harus dengan akte otentik (dengan notaris seperti yang ditetapkan dalam KUH Perdata). Bisa dibuat oleh para pihak (dibawah tangan) dan disahkan oleh pegawai pencatat nikah.

Dalam Kompilasi Hukum Islam terdapat dua bentuk perjanjian kawin sebelum dilangsungkan-nya perjanjian perkawinan, yaitu :

1. Taklik talak dan

2. Perjanjian lain yang tidak ber- 
tentangan dengan hukum islam.

Tentang perjanjian taklik talak tidak dianut dalam Undang-Undang Nomor 1 Tahun 1974, sedangkan dalam $\mathrm{KHI}$ diperbolehkan perjanjian kawin yang mengenai taklik talak. Sedangkan isi taklik talak tidak boleh bertentangan dengan hukum Islam (Pasal 46 ayat (1) Kompilasi Hukum Islam). Perjanjian taklik talak bukan suatu perjanjian yang wajib di adakan pada setiap perkawinan, akan tetapi sekali taklik talak sudah diperjanjikan tidak dapat dicabut kembali.

Apabila keadaan yang di syaratkan dalam taklik talak betul-betul terjadi kemudian, tidak dengan sendirinya talak jatuh. Agar talak tersebut sungguh terjadi, maka isteri harus mengajukan persoalannya (permohonan) ke Pengadilan Agama. Sehingga hal itu menunjukkan bahwa walaupun sudah terjadi adanya taklik talak tetapi prosedur beracara ke Pengadilan Agama tetap dilakukan. Dalam agama Islam, perjanjian pra nikah juga terdapat dalam Qur'an surat Al-Baqarah ayat 2 dan Hadits. Isinya menyatakan bahwa setiap mukmin terikat dengan perjanjian mereka msing-masing. Maksudnya, jika seorang mukmin sudah berjanji harus dilaksanakan.

Perjanjian pra nikah tidak diperbolehkan, jika perjanjian tersebut menghalalkan yang haram dan mengharamkan yang halal. Misalnya :

- Perjanjian yang isinya suami boleh nikah lebih dari empat isteri. Padahal seharusnya suami hanya boleh beristeri maksimal empat orang asal bisa berbuat adil.

- Perjanjian yang isinya, jika suami meninggal dan mereka tidak dikaruniai anak, warisan mutlak jatuh pada istri, padahal dalam Islam harta suami yang meninggal tanpa dikaruniahi seorang anak, tidak seluruhnya jatuh pada isteri, tapi juga pada Saudara kandung pihak suami serta orang tua suami yang masih hidup.

- Perjanjian yang isinya, bahwa perkawinan dibatasi waktunya yang kemudian bercerai. Karena pernikahan tidak boleh ada perjanjian untuk bercerai.

Perjanjian kawin selain Taklik talak ada perjanjian kawin yang mengenal harta perkawinan suami-isteri, asalkan 
tidak bertentangan dengan hukum Islam. Perjanjian kawin mengenai harta perkawinan meliputi percampuran harta pribadi dan pemisahan harta pencaharian masing-masing sepanjang hal itu tidak bertentangan dengan hukum Islam (Pasal 42 ayat (2) Kompilasi Hukum Islam). Dibuatnya perjanjian kawin mengenai pemisahan harta bersama atau harta syarikat, baik dipenuhi atau tidak perjanjian yang mereka buat, maka suami tetap berkewajiban menanggung biaya kebutuhan rumah tangga.

Perjanjian percampuran harta pribadi dapat meliputi semua harta, baik yang dibawa masing-masing ke dalam perkawinan (harta bawaan atau asal), maupun yang diperoleh oleh masingmasing selama perkawinan. Selain itu dapat juga diperjanjikan bahwa percampuran harta pribadi hanya terbatas pada harta pribadi yang dibawa pada saat perkawinan dilangsungkan, sehingga percampuran ini tidak meliputi harta pribadi yang diperoleh selama perkawinan atau sebaliknya (Pasal 49 ayat (2) Kompilasi Hukum Islam).

Perjanjian perkawinan mengenai harta, mengikat kepada para pihak dan pihak ketiga terhitung mulai tanggal dilangsungkannya perkawinan dihadapan Pegawai Pencatat Nikah.

Apabila suami ingin menikah dengan isteri kedua, ketiga atau keempat, boleh diperjanjikan mengenai tempat kediaman, waktu giliran dan biaya rumah tangga bagi isteri yang akan dinikahinya (Pasal 52Kompilasi Hukum Islam).

Pengaturan perjanjian perkawinan dalam Kompilasi Hukum Islaml lebih lengkap daripada Undang-Udang Nomor 1 Tahun 1974 tentang perkawinan. Adanya perjanjian kawin khususnya terhadap kedudukan harta perkawinan dalam berumah tangga sebenarnya penting, karena pengaturan mengenai harta perkawinan khususnya UndangUndang Nomor1 Tahun 1974 sangat kurang lengkap dan menimbulkan multi tafsir. Sedangkan adanya perjanjian kawin mewujudkan kesepakatan bagi suami ini terhadap hartanya.

Kesepakatan disini lebih cenderung pada hukum keluarga atau hubungan moral dalam keluarga. Jadi bukan kesepakatan yang di atur dalam Buku III KUH Perdata, tentang perikatan, yang lebih menitik beratkan pada 
keuntungan.

Jelaslah bahwa memang pengaturan harta perkawinan di atur dalam beberapa peraturan, namun yang berlaku adalah aturan dalam Undang-Undang Nomor 1 Tahun 1974. pengaturan tentang harta bersama yaitu harta yang diperoleh selama perkawinan. Namun mengenai warisan, hadiah yang diperoleh selama per-awinan tidak termasuk harta bersama, tetapi masuk harta bawaan atau harta masing-masing.

Dan apabila berkeinginan untuk menyimpangi aturan tentang harta perkawinan yang sudah ada, bisa melalui perjanjian kawin. Apabila dalam aturan Undang-Undang Nomor 1 Tahun 1974 kurang lengkap atau tidak ada maka bisa mengambil aturan yang lain berdasarkan Pasal 66 Undang-Undang Nomor 1 Tahun 1974 (dengan penafsiran a contrario).

Upaya hukum untuk mempertegas keberadaan harta perkawinan, bisa melalui perjanjian kawin. Walaupun kebanyakan adat ketimuran dan menjaga kekekalan dalam berumah tangga atau di dasarkan pada sifat untuk mengagungkan tali perkawinan, mereka (suami-isteri) beranggapan bawa tidak pantas, atau tabu untuk membicarakan pemisahan harta yang diperoleh atas usaha dan jerih payah pasangannya. Suami-isteri menyadari jika dalam perkawinan terdapat perjanjian mengenai harta mereka, maka sesungguhnya mereka tidak percaya dengan pasangan hidupnya. Namun dengan adanya upaya hukum dengan membuat perjanjian kawin sebenarnya untuk menangani problem dalam perebutan harta perkawinan mereka (apabila ada masalah) sehingga lebih mewujudkan kepastian hukum terhadap harta perkawinan pasangan suami-isteri.

\section{DAFTAR PUSTAKA}

CST. Kansil. Pengantar IImu hukum dan Tata hukum Indonesia. Cet. VIII, Balai Pustaka, Jakarta, 1989, Hal. 69.

H.K.N. Sofyan Hasan. Hukum Islam Bekal Pengantar IImu Hukum dan Tata Hukum Islam di Indonesia. Literata, Jakarta. 2004.

J. J. Satrio. Hukum Harta Perkawinan. PT. Citra Aditya Bakti, Bandung. 1991. Hal 27.

J.G. Klassen - J. Eggens - JM. Polak. Huwelijksgoederen en Erfrecht. Cet VIII, Tjeenk Wilink, Zwolle. 1956. Hal 3. 